\title{
Effect of Arbuscular Mycorrhizal Fungi on Switchgrass Growth and Mineral Nutrition in Cadmium-Contaminated Soil
}

\author{
Hong Sun ${ }^{1}$, Jintao Fu², Fuyu Yang ${ }^{2 *}$ \\ ${ }^{1}$ College of Tea, Guizhou University, Guizhou, PR China \\ ${ }^{2}$ Department of Grassland Science, College of Animal Science and Technology, \\ China Agricultural University, Beijing, PR China
}

Received: 6 January 2018

Accepted: 6 August 2018

\begin{abstract}
The effect of arbuscular mycorrhizal fungi (AMF) and cadmium (Cd) treatment on switchgrass (Panicum virgatum) growth, $\mathrm{Cd}$ accumulation, mineral element concentrations and soil Cd bioavailability were investigated in a greenhouse experiment. The results showed that switchgrass biomass increased with AMF inoculation at all Cd levels except the $40 \mathrm{mg} / \mathrm{kg} \mathrm{Cd}$ treatment. AMF decreased the shoots and roots $\mathrm{Cd}$ accumulation for the 10 and $40 \mathrm{mg} / \mathrm{kg}$ Cd treatments and limited $\mathrm{Cd}$ translocation from root to shoot, but enhanced the phosphorus concentrations for all $\mathrm{Cd}$ treatments. Furthermore, the presence of AMF reduced the reducible-extractable and acid-extractable $\mathrm{Cd}$ concentrations in the 10 and $40 \mathrm{mg} / \mathrm{kg} \mathrm{Cd}$ soils, respectively. AMF inoculation significantly increased the shoot $\mathrm{Ca}, \mathrm{Mg}, \mathrm{K}$, and $\mathrm{Na}$ concentrations without $\mathrm{Cd}$ addition; it decreased $\mathrm{Ca}, \mathrm{Mg}$, and $\mathrm{Zn}$ concentrations in the roots and $\mathrm{Fe}$ in the shoots with the low $\mathrm{Cd}$ addition; it increased $\mathrm{K}, \mathrm{Mg}$, and $\mathrm{Na}$ in the shoots with the $10 \mathrm{mg} / \mathrm{kg} \mathrm{Cd}$ addition; and it increased $\mathrm{Ca}$ and $\mathrm{Mg}$ in the shoots and $\mathrm{Na}$ in the roots with the $40 \mathrm{mg} / \mathrm{kg} \mathrm{Cd}$ addition. In summary, AMF inoculation decreased $\mathrm{Cd}$ absorption and translocation, improved $\mathrm{P}$ absorption, and took a different strategy to elements absorption under different $\mathrm{Cd}$ levels. The improved biomass and decreased Cd concentrations with AMF assistance increased the potential for switchgrass use as a phytoremediation and bioenergy crop in a contamination site.
\end{abstract}

Keywords: energy grass, AMF, heavy metal, nutrition element, bioavailability

\section{Introduction}

With increasing levels of economic development, pollution containing heavy metals originating from industry, mining and agriculture is becoming a serious

*e-mail: yfycau@163.com threat to the environment and humans - with $\mathrm{Cd}$ being the most toxic contaminant. Cd has the potential to inhibit plant growth by destroying the photosynthetic structure, disturbing nutrition absorptihe, decreasing root and leaf extension and even leading to death [1-2]. Cd can enter animals and humans through the food chain, causing kidney and reproductive function damage, osteoporosis and hypertension [3]. Thus, the remediation of $\mathrm{Cd}$-polluted soil to avoid $\mathrm{Cd}$ damage 
to plant growth and human health was an urgent undertaking.

Phytoremediation, a promising technology that uses plants to extract/stabilize contaminants from/in the soil is a low-cost, environmentally friendly technique compared to traditional remediation methods [4]. Most selected hyperaccumulators have low biomass and slow growth rates, restricting their long-term utilization and resulting in low economic benefit. The discovery of a plant species that could balance these features, decreasing time cost and promoting economic development - all while providing phytoremediation would be a favorable solution.

Energy crops have been introduced to produce biofuels to substitute for traditional fossil fuels in recent decades [5-6]. With the decreasing area of cultivated land available in the world, it is an excellent choice to cultivate energy crops on abandoned or contaminated land to extract/stabilize $\mathrm{Cd}$, improve the local ecological environment, produce energy biomass and prevent $\mathrm{Cd}$ from entering the food chain [7]. Consequently, many studies have been conducted on how to phytoremediate contaminated soil using energy grass, and a consensus has been reached that the utilization of high-biomass energy grass as phytoremediation material could be a profit-making operation [2, 8]. Switchgrass, a perennial rhizomatous grass, has a broad climate tolerance, rapid growth rate, high biomass yield, strong tolerance to low fertilizer level and varied abiotic and biotic stress; as proposed by Koçar and Civaş, these characteristics make up perfect phyroremediation materials [6]. Several studies have demonstrated that switchgrass has a strong tolerance to water and salinity stress [9-10]. Some studies have reported that switchgrass absorbed excessive Cs, $\mathrm{Rb}, \mathrm{Cd}, \mathrm{Cu}, \mathrm{Zn}$, and $\mathrm{Pb}$ in the portion belowground, where the accumulation capacity greatly relied on switchgrass cultivar, soil $\mathrm{pH}$ and duration [1, 8, 11-13]. Although relevant studies found that switchgrass has a certain tolerance to $\mathrm{Cd}$, the sharp growth inhibition by high Cd toxicity cannot be ignored $[1,14]$. In the search for a rapid solution to increase energy crop (switchgrass) biomass to compensate for low $\mathrm{Cd}$ accumulation in the portion above might be a new direction for sustainable bioenergy feedstock in contaminated soils.

AMF could form symbiotic relationships with $80 \%$ vascular plants on the earth, and have been widely recommended in recent years to promote the host plant phytoremediation process in contaminated polluted soil. AMF could connect the root with rhizosphere by fungal mycelium enhancing plant nutrient exploitation, especially P [15-16]. Nutrition improvement greatly increased plant biomass, which had the benefit of diluting the contaminants $[15,17]$. The mode of heavy metal absorption and translocation in roots and shoots was regulated by AMF based on the concentration in the soil and plant species [14, 18-20]. Simultaneously, heavy metals could be immobilized in the fungal structure or on the fungal surface through the formation of polyphosphates [16, 21-23]. In addition, AMF produced glomaline to cheale contaminate, and improved organic matter content and soil $\mathrm{pH}$ to decreasing the heavy metal bioavailability [24]. Therefore, AMF has been used as a biological fertilizer to enhance plant $\mathrm{Cd}$ tolerance by promoting nutrition absorption, affecting heavy metal absorption/translocation and improving soil characteristics [25].

However, there has been limited information available on AMF improving switchgrass tolerance to $\mathrm{Cd}$. Researchers have found that AMF could improve switchgrass growth in acidic soil and help use more nitrogen fertilizer with increasing temperatures [26-27]. Arora et al. reported that inoculated AMF could promote switchgrass germination, survival and biomass under various added $\mathrm{Cd}$ concentrations [14]; however, further mechanisms are needed to explain the function of AMF in the interaction between switchgrass and $\mathrm{Cd}$ stress. Therefore, in the present study we grew switchgrass cv. Summer under three $\mathrm{Cd}$ levels and inoculated with Rhizophagus irregularis (RI). We detected plant growth, $\mathrm{Cd}$, mineral element, and three soil $\mathrm{Cd}$ species concentration, and analyzed the mycorrhizal response of these factors to explore if AMF could increase the growth and tolerance of switchgrass seedlings to $\mathrm{Cd}$, change $\mathrm{Cd}$ translocation, affect the relationship between $\mathrm{Cd}$ and elements nutrition concentrations, and provide useful information for the sustainable use of this bioenergy feedstock on contaminated land.

\section{Materials and Methods}

\section{Growth Media Preparation}

Soil was collected from the Shangzhuang Experimental Station of China Agriculture University. The soil chemical properties were as follow: $\mathrm{pH}$ 6.8 (1:2.5 in water), available P $1.8 \%$, and cadmium $0.01 \mathrm{mg} / \mathrm{kg}$. The soil was air-dried and passed through a $2 \mathrm{~mm}$ mesh sieve. The sand (diameter $<0.5 \mathrm{~mm}$ ) was bought from Dasenlin Gardon material station, washed several times, and rinsed three times with deionized water. The soil and sand were mixed uniformly $(\mathrm{w} / \mathrm{w}=2: 1)$, and sterilized by gamma rays $(25 \mathrm{kGy}$, $10 \mathrm{MeVelecton}$ beam). Then the mixture was divided into three parts, to which was added one of the three concentrations of $\mathrm{Cd}$ (in the form of $\mathrm{CdCl}_{2} .5 \mathrm{H}_{2} \mathrm{O}$ ): $0 \mathrm{mg} / \mathrm{kg}, 10 \mathrm{mg} / \mathrm{kg}$, and $40 \mathrm{mg} / \mathrm{kg}$. Before planting, the medium was combined with basal nutrition consisting of $30 \mathrm{mg} / \mathrm{kg} \mathrm{P}, 120 \mathrm{mg} / \mathrm{kg} \mathrm{N}$, and $120 \mathrm{mg} / \mathrm{kg} \mathrm{K}$.

\section{Host Plant}

Seeds of switchgrass were provided by the Breeding Laboratory of Animal Science and Technology College of China Agriculture University. The seeds were sterilized with $10 \% \mathrm{H}_{2} \mathrm{O}_{2}$ for 20 minutes, washed clean using tap water, and rinsed three times with deionized water. The seeds were germinated until the radicles 
reached $3 \mathrm{~cm}$, and each pot had sown 10 seeds. The pots were thinned to 5 seeds in each pot two weeks later.

\section{AMF Preparation}

The Rhizophagus irregularis (R. irregularis) (BGC BJ09) was provided by Jingping Gai from the Resource and Environment College of China Agriculture College. The harvested inoculum consisted of a mixture of spores, hyphae and plant root fragments. $1 \mathrm{~g}$ inoculum included 150 spores.

\section{Pot Experiment}

The experiment was designed with three Cd levels $(0$, $10,40 \mathrm{Cdmg} / \mathrm{kg}$ ) and two AMF treatments (inoculation or non-inoculation with $R$. irregularis). Each treatment was replicated 6 times.

The $1.2 \mathrm{~kg}$ soil filled the plastic pots $(\varphi 19 \mathrm{~cm} \times$ height $17 \mathrm{~cm}$ ). When the soil reached $2 / 3$ of the pot, we added $25 \mathrm{~g}$ inoculum uniformly, then covered the rest of the culture on the top. The inoculum was sterilized at $121^{\circ} \mathrm{C}$ for 4 hours as uninoculated treatment. To keep the same soil bacteria series except AMF, the uninoculated treatment was supplied by $5 \mathrm{ml}$ filtrate that was passed through a 40 mesh sieve. The pots were watered by deionized water to maintain moisture content of $15 \%$ on a dry soil basis (55\% water-holding capacity). The experiment was conducted in a greenhouse with $16 \mathrm{~h} / 27^{\circ} \mathrm{C}$ day time and $8 \mathrm{~h} / 22^{\circ} \mathrm{C}$ night under natural light conditions.

\section{Harvest and Samples Analysis}

Nine weeks later, all the plants were harvested and separated by shoots and roots. The roots were carefully washed with tap water and deionized water. The roots were divided into two parts: the fresh part was used to determine colonization and the remainder was used to determine the dry weight, heated at $65^{\circ} \mathrm{C}$ for $48 \mathrm{~h}$. Forty-five 1-cm fine root fragments were collected from switchgrass roots for each replicate to determine the rate of colonization stained with aniline blue [28-29]. The dried materials were milled and digested by $\mathrm{HNO}_{3}$ and $\mathrm{H}_{2} \mathrm{O}_{2}(3: 1 \mathrm{v} / \mathrm{v})$ in a microwave-accelerated reaction system (MarsX; CEM) with a three-step digestion process. The concentrations of $\mathrm{Cd}, \mathrm{P}, \mathrm{Ca}, \mathrm{K}, \mathrm{Na}, \mathrm{Mg}$, and $\mathrm{Zn}$ were determined by inductively coupled plasmamass spectrometry (ICP-MS; model 7500a; Agilent Technologies). The samples without plant material addition were used for quality control to determine $\mathrm{Cd}$ and nutrition concentration. The soil $\mathrm{Cd}$ speciation was determined by the European Community Bureau of Reference (BCR) 3-step sequential extraction procedure.

\section{Statistical Analysis}

The translocation factor (TF) (Equation 1), the mycorrhizal response of $\mathrm{Cd}, \mathrm{P}, \mathrm{Ca}, \mathrm{Cu}, \mathrm{Fe}, \mathrm{K}, \mathrm{Mg}, \mathrm{Na}$, $\mathrm{Zn}$ and the mycorrhizal biomass response (Equation
2) were calculated to evaluate plant $\mathrm{Cd}$ tolerance and accumulation ability by below equations.

Translocation factor $=$
shoot metal concentration of dry plant
root metal concentration of dry plant
Mycorrhizal response $(\%)=$
elements content (M plant ) - mean element content (NM plant)
mean element content (NM plant)
$\times 100$

The data mean values for all treatments were compared using Duncan's multiple range test with SPSS17.0 software. The $\mathrm{Cd}$ concentration, soil $\mathrm{Cd}$ species, and nutrition concentration $(\mathrm{P}, \mathrm{Ca}, \mathrm{Fe}, \mathrm{K}, \mathrm{Mg}$, $\mathrm{Na}$, and $\mathrm{Zn}$ ) were analyzed with a two-way ANOVA to evaluate the influences of mycorrhizal inoculation treatment and $\mathrm{Cd}$ addition.

\section{Results and Discussion}

\section{Root Colonization and Biomass}

The root colonization under three $\mathrm{Cd}$ addition levels is shown in Fig. 1a). With 0 and $10 \mathrm{mg} / \mathrm{kg} \mathrm{Cd}$ addition, the switchgrass roots were greatly colonized by AMF, which reached $80 \%$; however, colonization decreased to $41 \%$ with the $40 \mathrm{mg} / \mathrm{kg} \mathrm{Cd}$ addition $(\mathrm{P}<0.01)$.

The shoot and root biomass were significantly affected by the AMF inoculation under different $\mathrm{Cd}$ treatments $(\mathrm{P}<0.001$, Fig. 1b). The biomass of inoculated switchgrass was significantly higher than in the corresponding noninoculated treatment with the 0 and $10 \mathrm{mg} / \mathrm{kg} \mathrm{Cd}$ addition, and was increased by $320 \%$ and $477 \%$ in the shoots, and $270 \%$ and $858 \%$ in the roots, respectively. There were no significant differences with AMF absence and presence under the $40 \mathrm{mg} / \mathrm{kg} \mathrm{Cd}$ addition level $(\mathrm{P}>0.05)$.

Biomass is the most important factor for evaluating whether a plant could be an energy crop or phytoremediation species. Compared with noninoculated treatment, the shoot and root biomass in the presence of $R$. irregularis increased by $320 \%$ and $270 \%$, respectively, for the $0 \mathrm{mg} / \mathrm{kg} \mathrm{Cd}$ treatment, and increased by $477 \%$ and $858 \%$ for the $10 \mathrm{mg} /$ $\mathrm{kg} \mathrm{Cd}$ treatment. RI-symbiosis growth acceleration was observed in Helianthus annuus, Lotus japonicas, and Oryza sativa under different $\mathrm{Cd}$ addition levels [17, 30-31]. AMF inoculation could improve plant photosynthesis and, through external hyphae, expand root surface to improve plant nutrition status. However, there were no significant differences between inoculated and non-inoculated samples with the $40 \mathrm{mg} / \mathrm{kg} \mathrm{Cd}$ treatment; even the biomass mycorrhizal response was negative when soil $\mathrm{Cd}$ reached $40 \mathrm{mg} / \mathrm{kg}$. Zhang et al. found the host plants growth promotion blocked when the soil $\mathrm{Cd}$ reached 
a)
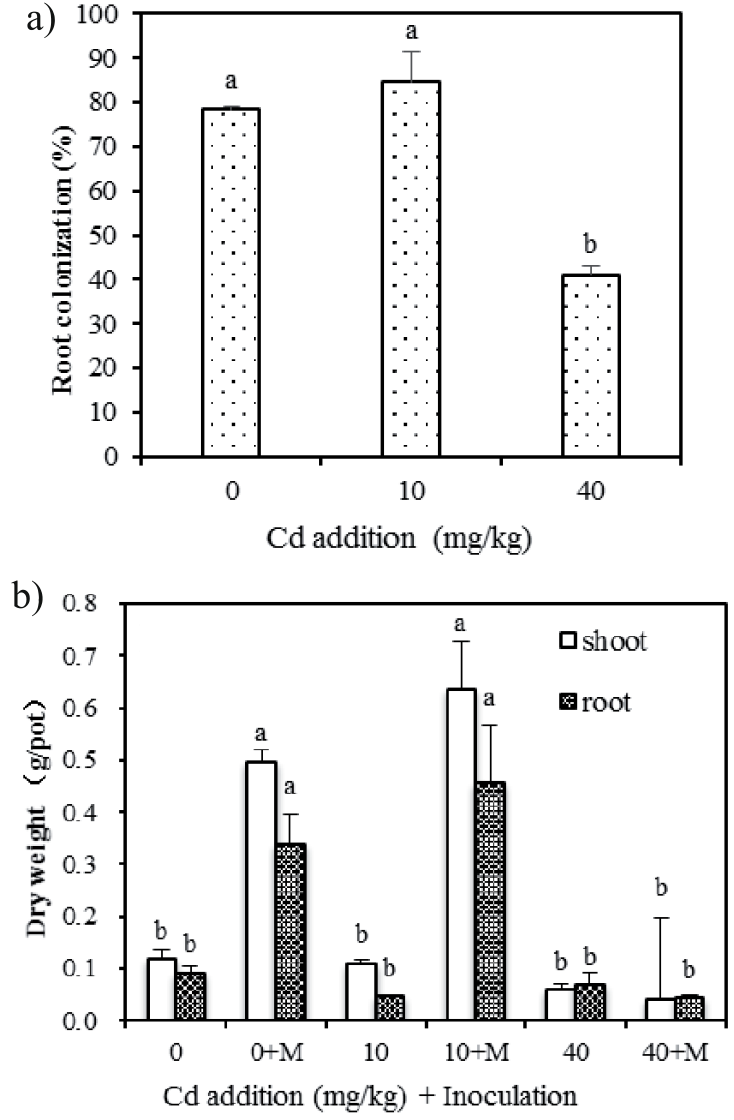

Fig. 1. The root colonization and dry weights of switchgrass with AMF inoculation under three $\mathrm{Cd}$ levels. $\mathrm{M}$ represent inoculation with Rhizophagus irregularis. Bars above the columns represent the standard errors $(n=3)$. Different letters above the column represent the significant differences under three $\mathrm{Cd}$ level, regardless of inoculations. These descriptions are same to the blow figures.
$50 \mathrm{mg} / \mathrm{kg}$, which indicated that AMF acted as an obstruction in the plant under high Cd stress [17].

\section{Cd and P Accumulation in Shoots and Roots}

The $\mathrm{Cd}$ and $\mathrm{P}$ concentrations of switchgrass in shoots and roots under three $\mathrm{Cd}$ addition levels with inoculation and noninoculation are shown in Table 1. The results show that these concentrations were significantly influenced by $\mathrm{Cd}$ addition and AMF inoculation. $P$ concentrations were affected by their interaction $(\mathrm{P}<0.01, \mathrm{P}<0.001$, Table 2$)$, whereas nonsignificant differences were observed in root $\mathrm{Cd}$ concentration by inoculation and their interaction, and were the same as the effect of $\mathrm{Cd}$ addition on the shoot $\mathrm{P}$ concentrations ( $\mathrm{P}>0.05$, Table 2$)$.

As the soil Cd levels increased, the shoot and root $\mathrm{Cd}$ concentrations decreased with AMF symbiosis, with the 10 and $40 \mathrm{mg} / \mathrm{kg} \mathrm{Cd}$ additions, the $\mathrm{Cd}$ levels decreased by $68 \%, 36 \%$ in the shoots, and $-8 \%$ and $11 \%$ in the roots, respectively. The $\mathrm{Cd}$ translocation factors (TFs) were higher in the 0 and $10 \mathrm{mg} / \mathrm{kg} \mathrm{Cd}$ treatment without AMF symbiosis, and the Cd TFs for the AMF-inoculated samples were lower than those of noninoculated samples irrespective of $\mathrm{Cd}$ addition. Substantial increases were observed in shoot and root $\mathrm{P}$ concentrations with AMF presence under all $\mathrm{Cd}$ treatments, with increases of $702 \%, 271 \%$, and $332 \%$ in the shoots, and $285 \%, 99 \%, 143 \%$ in the roots for the 0,10 and $40 \mathrm{mg} / \mathrm{kg} \mathrm{Cd}$ treatments, respectively. The TFs of $\mathrm{P}$ remained stable under three $\mathrm{Cd}$ concentrations, irrespective of inoculation; however, the inoculated TFs of $\mathrm{P}$ were higher than those of the corresponding noninoculated sample under the three $\mathrm{Cd}$ concentrations.

Table 1. The concentration and translocation factor of $\mathrm{Cd}(\mathrm{mg} / \mathrm{kg})$ and $\mathrm{P}(\mathrm{g} / \mathrm{kg})$ in switchgrass with AMF inoculation under three Cd levels.

\begin{tabular}{|c|c|c|c|c|c|c|c|}
\hline \multirow{2}{*}{ Cd level(mg/kg) } & \multirow{2}{*}{$\mathrm{AMF}$} & \multicolumn{3}{|c|}{ Cd Concentration } & \multicolumn{3}{|c|}{ P concentration } \\
\hline & & Shoot & Root & TF-Cd & Shoot & Root & TF-P \\
\hline \multirow{2}{*}{0} & NM & $0.20 \pm 0.0 .17 b$ & $0.63 \pm 0.09 \mathrm{~d}$ & $0.68 \pm 0.63$ & $0.47 \pm 0.14 \mathrm{c}$ & $1.02 \pm 0.02 \mathrm{~d}$ & $0.47 \pm 0.14 b$ \\
\hline & M & $0.07 \pm 0.03 b$ & $0.73 \pm 0.13 \mathrm{~d}$ & $0.11 \pm 0.03$ & $3.77 \pm 0.39 \mathrm{a}$ & $3.93 \pm 0.07 \mathrm{a}$ & $1.11 \pm 0.09 \mathrm{a}$ \\
\hline \multirow{2}{*}{10} & NM & $21.73 \pm 4.17 \mathrm{a}$ & $68.43 \pm 12.05 \mathrm{c}$ & $0.38 \pm 0.03$ & $0.59 \pm 0.13 \mathrm{c}$ & $0.81 \pm 0.06 \mathrm{~d}$ & $0.72 \pm 0.14 b$ \\
\hline & M & $7.03 \pm 1.60 \mathrm{~b}$ & $73.77 \pm 3.62 \mathrm{c}$ & $0.09 \pm 0.02$ & $2.19 \pm 0.25 b$ & $1.61 \pm 0.08 \mathrm{c}$ & $1.36 \pm 0.11 \mathrm{a}$ \\
\hline \multirow{2}{*}{40} & NM & $36.74 \pm 3.8 \mathrm{a}$ & $281.97 \pm 14.48 \mathrm{a}$ & $0.13 \pm 0.02$ & $0.59 \pm 0.11 \mathrm{c}$ & $0.79 \pm 0.08 \mathrm{e}$ & $0.78 \pm 0.19 \mathrm{ab}$ \\
\hline & M & $23.43 \pm 7.25 \mathrm{a}$ & $250.47 \pm 20.44 b$ & $0.09 \pm 0.02$ & $2.55 \pm 0.55 b$ & $1.92 \pm 0.17 \mathrm{~b}$ & $1.15 \pm 0.35 \mathrm{a}$ \\
\hline \multicolumn{8}{|c|}{ Significance of } \\
\hline \multicolumn{2}{|c|}{ Cadmium (Cd) } & $* * *$ & $* * *$ & ns & ns & $* * *$ & $* *$ \\
\hline \multicolumn{2}{|c|}{ Inoculation (I) } & $* *$ & ns & ns & $* * *$ & $* * *$ & ns \\
\hline \multicolumn{2}{|l|}{$\mathrm{Cd} \times \mathrm{I}$} & ns & ns & ns & $*$ & $* * *$ & ns \\
\hline
\end{tabular}

NM and M represent noninoculated and inoculated with Rhizophagus irregularis, respectively. Different letters in the same column represent the significant differences among three Cd levels, regardless of inoculation. ns represent $\mathrm{P}>0.05$, * represent $\mathrm{P}<0.05$, ** represent $\mathrm{P}<0.01$, *** represent $\mathrm{P}<0.001$. It is same in the below tables. 
These results showed that AMF symbiosis took a contrasting strategy to $\mathrm{P}$ and $\mathrm{Cd}$ translocation.

In our study, $\mathrm{AMF}$ inoculation reduced switchgrass shoot $\mathrm{Cd}$ concentrations with the 10 and $40 \mathrm{mg} / \mathrm{kg} \mathrm{Cd}$ additions (Table 1). These results were consistent with those of Aghababaei et al. and Jiang et al., who reported that inoculated R. irregularis obviously decreased $\mathrm{Cd}$ concentration in the shoots of Zea mays and Lonicera japonica under the 10 and $20 \mathrm{mg} / \mathrm{kg} \mathrm{Cd}$ conditions [3233]. The decreased $\mathrm{Cd}$ concentrations might be a result of the dilution effects of biomass promotion by AMF inoculation. However, the findings disagreed with the above results reported by Zhang et al. and Liu et al. who found AMF could improve $\mathrm{Cd}$ concentrations in both shoots and roots in Lotus japonicas and Solanum nigrum with different $\mathrm{Cd}$ addition levels $[17,19]$. It is possible that the contradictory $\mathrm{Cd}$ concentration in plants may be explained by the varied plant and AMF species used or due to the different soil characteristics ( $\mathrm{pH}, \mathrm{Cd}$ concentration) [34].

AMF symbiosis not only affected the absolute $\mathrm{Cd}$ concentration in the tissue, but also alerted their translocation. In the present study, the $\mathrm{TF}$ of $\mathrm{Cd}$ with AMF symbiosis was lower than that of the corresponding non-inoculated treatment at every $\mathrm{Cd}$ level, and the $\mathrm{TF}$ values were much lower than 1 . It was the consensus that AMF could alleviate $\mathrm{Cd}$ direct damage to photosynthetic organs by inhibiting $\mathrm{Cd}$ translocation from the root to shoot compared with AMF absence. AMF helped the plant to retain most of the $\mathrm{Cd}$ in mycorrhizal roots by compartmenting $\mathrm{Cd}$ in root cell walls and vacuoles or directly immobilizing the contaminants in the structure of AMF, such as the extra- or intra-radical mycelia, arbuscular or vesicles $[22-23,35]$

AMF are known to increase plant nutrition status, especially for $\mathrm{P}$ levels. In the present study, the $\mathrm{P}$ concentrations with AMF inoculation were higher than with noninoculated treatment for all $\mathrm{Cd}$ levels regardless of plant tissue, and a positive mycorrhizal of $\mathrm{P}$ response was observed in each level (Table 1, Table 3). Previous results suggested that the increased plant tissue $P$ concentrations could be another strategy to counteract $\mathrm{Cd}$ toxicity, regardless of inoculation [17, 36]. In addition to accelerating plant growth, $\mathrm{P}$ could alleviate $\mathrm{Cd}$ toxicity by decreasing tissue $\mathrm{Cd}$ uptake or forming phosphate complexes to chelate $\mathrm{Cd}$ on the root surface [16]. P could also enhance the sequestration of $\mathrm{Cd}$ in AMF by the accumulation of polyphosphate in the AMF extraradical hyphae $[22,23]$. Therefore, the regulation of $\mathrm{P}$ nutrition could be a mutually beneficial action for plant growth and $\mathrm{Cd}$ detoxification in plant tissue.

\section{Soil Cd Sspecies}

The amounts of acid-extractable, reducible $\mathrm{Cd}$ in the plants were significantly affected by $\mathrm{Cd}$ addition and inoculation treatment $(\mathrm{P}<0.001, \quad \mathrm{P}<0.05)$, and the concentrations of acid-extractable, reducible and oxidizable $\mathrm{Cd}$ were increased with the soil $\mathrm{Cd}$ increasing (Table 2). The reducible-Cd content with $10 \mathrm{mg} / \mathrm{kg} \mathrm{Cd}$ addition and acid-extractable content with $40 \mathrm{mg} / \mathrm{kg} \mathrm{Cd}$ addition with $R$. irregularis symbiosis were both lower than that of the corresponding noninoculated treatment. However, no significant difference was observed for other soil $\mathrm{Cd}$ species between the noninoculated and inoculated samples under different $\mathrm{Cd}$ addition levels $(\mathrm{P}>0.05)$.

The bio-toxicity of heavy metals was regulated by the total metal amount and metal species, with the latter determining metal bioavailability. Our results showed that the main $\mathrm{Cd}$ species was acid-extractable, as shown by Chen et al. [1]. Although the inoculated treatment did not affect the total $\mathrm{Cd}$ concentration in soil, the present study found that $R$. irregularis could change soil $\mathrm{Cd}$ species, decreasing acid-extractable $\mathrm{Cd}$ at low $\mathrm{Cd}$ levels and reducible-Cd at high $\mathrm{Cd}$ stress with RI symbiosis. Previous studies indicated that soil $\mathrm{Cd}$ species might change into more stable forms, but owing to the limitations of our experimental apparatus, we could not confirm whether the $\mathrm{Cd}$ transformed into an exchangeable or residual form [37-38]. AMF could

Table 2. The concentration of three Cd species (acid-extractable, reducible and oxidizable Cd) in the soil with AMF inoculation under three $\mathrm{Cd}$ levels.

\begin{tabular}{|c|c|c|c|c|c|c|}
\hline \multirow{2}{*}{ Cd level } & \multicolumn{2}{|c|}{ Acid-extractable Cd } & \multicolumn{2}{|c|}{ Reducible-Cd } & \multicolumn{2}{|c|}{ Oxidizable-Cd } \\
\hline & NM & M & NM & M & NM & M \\
\hline 0 & 0 & 0 & 0 & 0 & 0 & 0 \\
\hline 10 & $10.41 \mathrm{~b}$ & $10.61 \mathrm{~b}$ & $11.67 \mathrm{a}$ & $10.86 \mathrm{~b}$ & $0.00 \mathrm{c}$ & $1.05 \mathrm{c}$ \\
\hline 40 & $44.93 \mathrm{a}$ & $41.88 \mathrm{~b}$ & $8.97 \mathrm{c}$ & $9.68 \mathrm{c}$ & $3.59 \mathrm{~d}$ & $4.97 \mathrm{~d}$ \\
\hline \multicolumn{7}{|c|}{ Significance of } \\
\hline $\mathrm{Cd}$ & \multicolumn{2}{|c|}{$* * *$} & \multicolumn{2}{|c|}{$* * *$} & \multicolumn{2}{|c|}{$* * *$} \\
\hline I & \multicolumn{2}{|c|}{$* *$} & \multicolumn{2}{|c|}{$*$} & \multicolumn{2}{|c|}{ ns } \\
\hline $\mathrm{Cd} \times \mathrm{I}$ & \multicolumn{2}{|c|}{$* *$} & \multicolumn{2}{|c|}{$\mathrm{ns}$} & \multicolumn{2}{|c|}{$\mathrm{ns}$} \\
\hline
\end{tabular}

Different letters in the same Cd level represent the significant differences among three Cd levels, regardless of inoculation. 
Table 3. Mycorrhizal response of biomass (\%MGR), Cd (\%MCdR), P(\%MPR), $\quad \mathrm{Ca}(\% \mathrm{MCaR}), \quad \mathrm{Cu}(\% \mathrm{MCuR})$, $\mathrm{Fe}(\% \mathrm{MFeR}), \quad \mathrm{K}(\% \mathrm{MKR}), \quad \mathrm{Mg}(\% \mathrm{MMgR}), \quad \mathrm{Na}(\% \mathrm{MNaR})$, $\mathrm{Zn}(\% \mathrm{MZnR})$ in the soil under three $\mathrm{Cd}$ additions.

\begin{tabular}{|c|c|c|c|}
\hline & 0 & 10 & 40 \\
\hline$\% M G R$ & $298.5 \pm 59 \mathrm{~b}$ & $589.8 \pm 155 \mathrm{c}$ & $-35.4 \pm 5 \mathrm{a}$ \\
\hline$\% \mathrm{MCdR}$ & $-28 \pm 13$ & $8 \pm 6$ & $-14 \pm 6$ \\
\hline$\% \mathrm{MPR}$ & $381 \pm 31 \mathrm{a}$ & $170 \pm 23 \mathrm{~b}$ & $196 \pm 38 \mathrm{~b}$ \\
\hline$\% \mathrm{MCaR}$ & $2 \pm 5 \mathrm{a}$ & $-40 \pm 10 \mathrm{~b}$ & $23 \pm 4 \mathrm{a}$ \\
\hline$\% \mathrm{MFeR}$ & $-15 \pm 9$ & $-23 \pm 13$ & $6 \pm 20$ \\
\hline$\% \mathrm{MKR}$ & $112 \pm 7 \mathrm{a}$ & $57 \pm 18 \mathrm{~b}$ & $9 \pm 8 \mathrm{c}$ \\
\hline$\% \mathrm{MMgR}$ & $1 \pm 5$ & $-8 \pm 9$ & $10 \pm 5$ \\
\hline$\% \mathrm{MNaR}$ & $104 \pm 11$ & $74 \pm 4$ & $68 \pm 15$ \\
\hline$\% \mathrm{MZnR}$ & $3 \pm 7 \mathrm{a}$ & $-44 \pm 10 \mathrm{~b}$ & $-63 \pm 2 \mathrm{~b}$ \\
\hline
\end{tabular}

Different letters in the line represent the significant differences among three $\mathrm{Cd}$ levels.

secrete glomalin to chelate toxic elements and alter the soil $\mathrm{pH}$ in order to influence metal availability [24]. Some researchers also found that AMF symbiosis raised metal bioavailability in plants. Subramanian et al. reported that under different $\mathrm{Zn}$ addition levels, inoculated AMF increased organically bound $\mathrm{Zn}$ with decreasing residual and crystalline oxides of $\mathrm{Zn} \mathrm{[39].} \mathrm{Wu} \mathrm{et} \mathrm{al.} \mathrm{reported}$ that with AMF inoculation treatment, the main $\mathrm{Cr}$ species in soil was oxidizable-Cr, and acid-extractable $\mathrm{Cr}$ concentrations decreased in dandelion (Taraxacum mongolicum) in the presence of $R$. irregularis presence [40]. In addition, Kumar et al. reported that AMF could regulate plants to secrete various compounds to alter the soil metal species, encourage translocation of essential metals (e.g., $\mathrm{Zn}$ and $\mathrm{Cu}$ ) to shoots, and fix toxic metals (e.g., $\mathrm{Cd}$ and $\mathrm{Pb}$ ) in roots or the rhizosphere to avoid destroying photosynthetic organs [41].

\section{Mineral Elements Concentration}

The concentrations of $\mathrm{Ca}, \mathrm{Fe}, \mathrm{K}, \mathrm{Mg}, \mathrm{Na}$, and $\mathrm{Zn}$ in the shoots and roots of switchgrass are shown in Fig. 2. The concentrations of $\mathrm{Ca}, \mathrm{Fe}, \mathrm{K}, \mathrm{Mg}$, and $\mathrm{Na}$ in the shoots and $\mathrm{K}$ and $\mathrm{Mg}$ in the roots were significantly affected by $\mathrm{Cd}$ addition. AMF inoculation significantly affected concentrations of $\mathrm{Ca}, \mathrm{K}, \mathrm{Mg}$, and $\mathrm{Na}$ in the shoots and $\mathrm{Ca}, \mathrm{K}, \mathrm{Mg}, \mathrm{Na}$, and $\mathrm{Zn}$ in the roots; $\mathrm{Cd}$ addition and AMF inoculation showed significant observable influences on $\mathrm{Ca}$ and $\mathrm{K}$ contents the in shoots and roots of $\mathrm{K}$ and $\mathrm{Mg}$ content in the roots $(\mathrm{P}<0.05$; $\mathrm{P}<0.01 ; \mathrm{P}<0.001$, Table 4).

The concentrations of $\mathrm{Ca}, \mathrm{K}, \mathrm{Mg}$, and $\mathrm{Na}$ in the shoots, and $\mathrm{Na}$ and $\mathrm{K}$ in the roots with $\mathrm{AMF}$ symbiosis were higher than those in the corresponding noninoculated samples under the three $\mathrm{Cd}$ addition levels, the exception was for $\mathrm{Ca}$ and $\mathrm{K}$ contents in the shoots with the $10 \mathrm{mg} / \mathrm{kg} \mathrm{Cd}$ treatment and $\mathrm{K}$ content in the roots with the $40 \mathrm{mg} / \mathrm{kg} \mathrm{Cd}$ treatment - none of which had any significant differences either with or without AMF inoculation. However, diminishing trends were observed in roots for the $\mathrm{Mg}$ content at all $\mathrm{Cd}$ levels and for the $\mathrm{Zn}$ content with the 10 and $40 \mathrm{mg} / \mathrm{kg} \mathrm{Cd}$ addition: in the roots, the $\mathrm{Mg}$ levels decreased by $28 \%, 35 \%$ and $5 \%$, for 0,10 and $40 \mathrm{mg} / \mathrm{kg}$ $\mathrm{Cd}$ additions, respectively; and the $\mathrm{Zn}$ levels decreased by $18 \%, 24 \%$ in the shoots, $28 \%$ and $24 \%$ in the roots with the 10 and $40 \mathrm{mg} / \mathrm{kg} \mathrm{Cd}$ additions, respectively. For the inoculated treatment with $10 \mathrm{mg} / \mathrm{kg} \mathrm{Cd}$, the roots $\mathrm{Ca}$ content and shoots $\mathrm{Fe}$ content were significantly lower than non-inoculated treatment, which decreased by $57 \%$ and $29 \%$, respectively.

Except for $\mathrm{P}$, inoculation with AMF also influenced the plant strategy for element nutrient uptake. In the absence of $\mathrm{Cd}$, the concentrations of $\mathrm{Ca}$ and $\mathrm{Mg}$ in the shoots, and $\mathrm{K}$ and $\mathrm{Na}$ in the shoots and roots with $\mathrm{AMF}$ symbiosis were higher than non-inoculated treatment. A previous study showed that under acid stress AMF could increase switchgrass absorption of $\mathrm{P}, \mathrm{Ca}, \mathrm{Mg}$ and $\mathrm{Zn}$ to reduce Fe absorption [26]. Sarkar et al. reported that $\mathrm{K}, \mathrm{Mg}, \mathrm{Fe}, \mathrm{Cu}$, and $\mathrm{Zn}$ concentrations increased in Miscanthus sacchariflorus with AMF symbiosis in river sand [42]. For now, a consensus has not been reached on the relationship between $\mathrm{Cd}$ and the mineral elements due to synergy or competition, not to mention the interaction from $\mathrm{Cd}$ and AMF. Wang et al. found that for Phragmites Australis, inoculation with $R$. irregularis increased the total concentrations of $\mathrm{Cu}, \mathrm{Fe}$, and $\mathrm{Ca}$ when the soil $\mathrm{Cd}$ is in the range of $0.01-20 \mathrm{mg} / \mathrm{L} \mathrm{[43].}$ In our study, the root $\mathrm{Ca}, \mathrm{Mg}$, and $\mathrm{Zn}$ levels decreased with AMF symbiosis under the $10 \mathrm{mg} / \mathrm{kg} \mathrm{Cd}$ addition, and the same trends were detected for the shoots $\mathrm{Fe}$ and $\mathrm{Mg}$ concentrations. The reason for this observation may be because of the "dilution effect" of plant biomass promotion with AMF. In addition, the shoot $\mathrm{Ca}, \mathrm{Mg}$, and $\mathrm{Na}$ with $40 \mathrm{mg} / \mathrm{kg} \mathrm{Cd}$ in the soil were higher than with $0 \mathrm{mg} / \mathrm{kg} \mathrm{Cd}$. These results suggested that AMF could enhance $\mathrm{Ca}, \mathrm{Mg}$, and $\mathrm{Na}$ translocations in the shoots to limit $\mathrm{Cd}$ translation from roots to shoots under high Cd levels, which is similar to the results reported by de Andrade et al. in sunflowers with AMF symbiosis [30]. The $\mathrm{K}$ concentrations with 10 and $40 \mathrm{mg} / \mathrm{kg} \mathrm{Cd}$ addition were lower than with the $0 \mathrm{mg} / \mathrm{kg} \mathrm{Cd}$ additions, similar to the results reported by Wang et al. [43]. This finding might be related to the relationship between $\mathrm{Cd}$ and the channel that regulates $\mathrm{K}^{+}$transmembrane transport from solutions, which would open when $\mathrm{Cd}^{2+}$ were the binding metal ion instead of $\mathrm{K}^{+}$[44-45]. Thus, excessive $\mathrm{Cd}$ obstructed $\mathrm{K}$ absorption by binding competition within the channel, resulting in decreased $\mathrm{K}$ absorption, regardless of inoculation.

\section{Mycorrhizal Response}

The Mycorrhizal response of total biomass and the $\mathrm{Cd}, \mathrm{P}, \mathrm{Ca}, \mathrm{Cu}, \mathrm{Fe}, \mathrm{K}, \mathrm{Mg}, \mathrm{Na}$, and $\mathrm{Zn}$ concentrations under the three $\mathrm{Cd}$ addition levels are shown in Table 
3. The mycorrhizal response of the biomass initially increased and then decreased when the soil $\mathrm{Cd}$ reached $40 \mathrm{mg} / \mathrm{kg}$. The mycorrhizal responses of $\mathrm{P}, \mathrm{Ca}, \mathrm{K}$ and $\mathrm{Zn}$ significantly decreased with soil $\mathrm{Cd}$ increases $(\mathrm{P}<0.05)$, but the mycorrhizal response of $\mathrm{Cd}, \mathrm{Fe}, \mathrm{Mg}$ and $\mathrm{Na}$ had no significant differences among three $\mathrm{Cd}$ levels $(\mathrm{P}>0.05)$. The total $\% \mathrm{MCdR}$ were positive under the $10 \mathrm{mg} / \mathrm{kg} \mathrm{Cd}$ and negative under the $40 \mathrm{mg} / \mathrm{kg} \mathrm{Cd}$ addition levels.

$\mathrm{Wu}$ et al. reported the negative mycorrhizal response of $\mathrm{Cr}$ in Bermudagrass with $R$ irregularis presence [40]. This outcome was in contrast to that of Zhang et al., who found the positive response to $\mathrm{Cd}$ in Lotus japonicas with $R$ irregularis symbiosis. This suggested that mycorrhizal response to heavy metal depends on the contaminant and plant species [17]. In addition, the $\% \mathrm{MCdR}$ was negative in shoots for $10 \mathrm{mg} / \mathrm{kg}$ and positive in roots for $10 \mathrm{mg} / \mathrm{kg} \mathrm{Cd}$ levels, and the results further verified that AMF accelerated the $\mathrm{Cd}$ accumulation in the roots under low $\mathrm{Cd}$ addition. Negative responses to $\mathrm{Ca}(10 \mathrm{mg} / \mathrm{kg}), \mathrm{Mg}$ $(10 \mathrm{mg} / \mathrm{kg}$ ) and $\mathrm{Zn}(10$ and $40 \mathrm{mg} / \mathrm{kg}$ ) were detected, possibly because AMF inhibited their absorption to inhibit $\mathrm{Cd}$ intake. Considering the negative response observed for Fe with AMF symbiosis, the correlation analysis showed that $\mathrm{Fe}$ was significantly negative a)

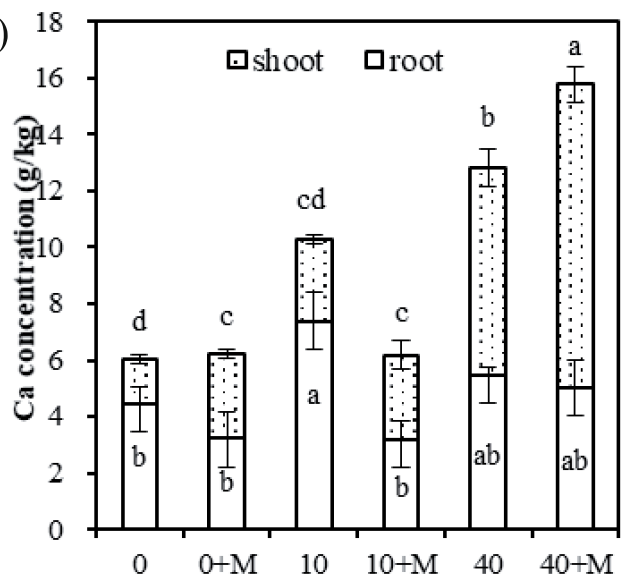

c)

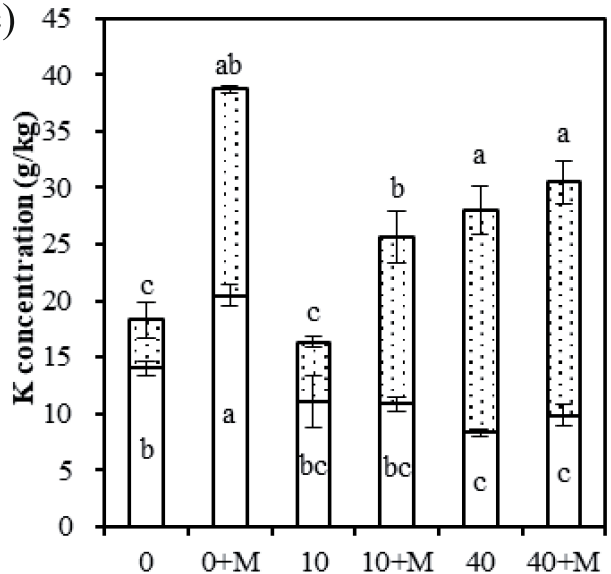

e)

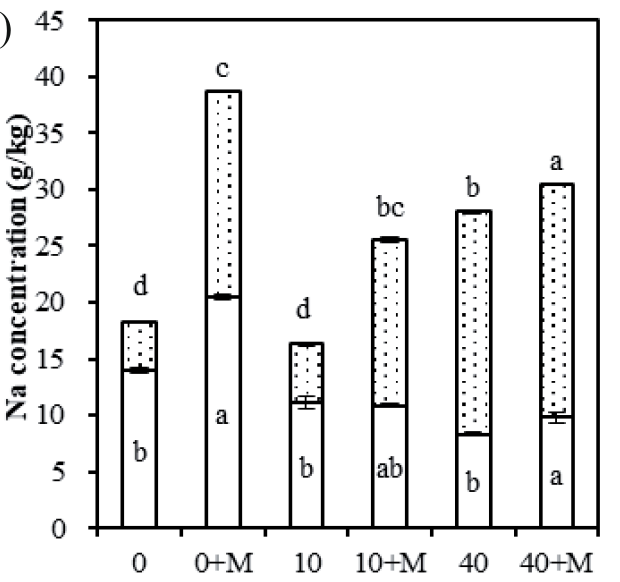

b)

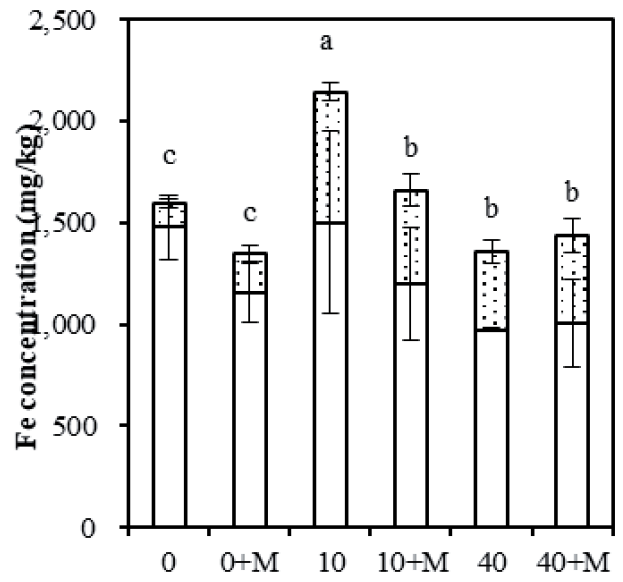

d)

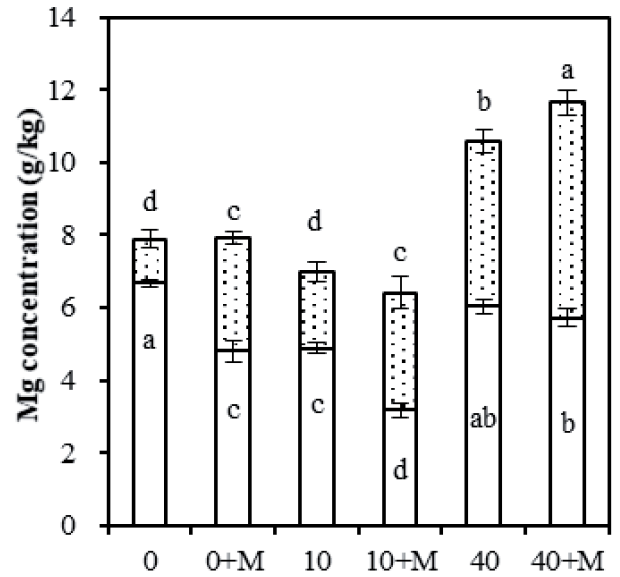

f)

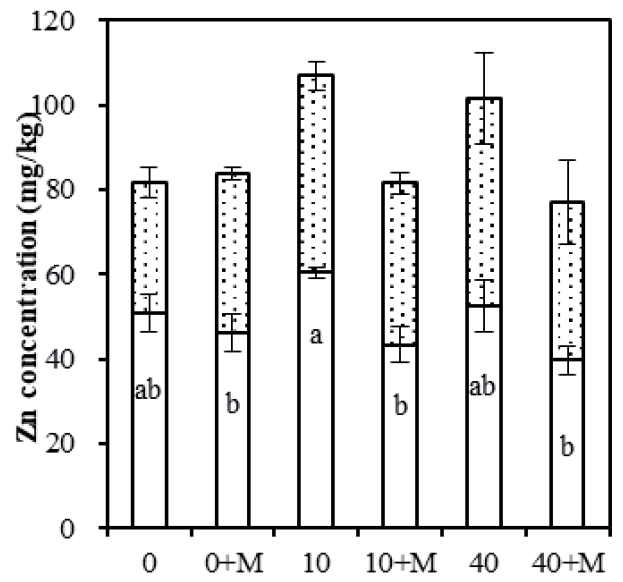

Fig. 2. The concentrations of $\mathrm{Ca}, \mathrm{Cu}, \mathrm{Fe}, \mathrm{K}, \mathrm{Mg}, \mathrm{Na}$, and $\mathrm{Zn}$ in switchgrass with $\mathrm{AMF}$ inoculation under three $\mathrm{Cd}$ levels. 
Table 4. ANOVA analysis the effect of $\mathrm{Cd}$ addition and inoculation treatment on $\mathrm{Ca}, \mathrm{Fe}, \mathrm{K}, \mathrm{Mg}, \mathrm{Na}$ and $\mathrm{Zn}$ concentrations.

\begin{tabular}{|c|c|c|c|c|c|c|}
\hline \multirow{2}{*}{} & \multicolumn{2}{|c|}{$\mathrm{Cd}$} & \multicolumn{2}{c|}{ Inoculation } & \multicolumn{2}{c|}{$\mathrm{Cd} \times \mathrm{I}$} \\
\cline { 2 - 7 } & Shoot & Root & Shoot & Root & Shoot & Root \\
\hline $\mathrm{Ca}$ & $0.000^{* * *}$ & 0.222 & $0.001^{* *}$ & $0.020^{*}$ & $0.009^{* *}$ & $0.127^{\text {ns }}$ \\
\hline $\mathrm{Fe}$ & $0.000^{* * *}$ & $0.311^{\text {ns }}$ & $0.697^{\text {ns }}$ & $0.354^{\text {ns }}$ & $0.085^{\text {ns }}$ & $0.735^{\text {ns }}$ \\
\hline $\mathrm{K}$ & $0.000^{* * *}$ & $0.000^{* * *}$ & $0.000^{* * *}$ & $0.017^{*}$ & $0.006^{* *}$ & $0.036^{*}$ \\
\hline $\mathrm{Mg}$ & $0.000^{* * *}$ & $0.000^{* * *}$ & $0.000^{* * *}$ & $0.000^{* * *}$ & $0.455^{\text {ns }}$ & $0.006^{* *}$ \\
\hline $\mathrm{Na}$ & $0.000^{* * *}$ & $0.495^{\text {ns }}$ & $0.000^{* * *}$ & $0.000^{* * *}$ & $0.167^{\text {ns }}$ & $0.380^{\text {ns }}$ \\
\hline $\mathrm{Zn}$ & 0.341 & $0.413^{\text {ns }}$ & 0.409 & $0.006^{* *}$ & $0.338^{\text {ns }}$ & $0.356^{\text {ns }}$ \\
\hline
\end{tabular}

ns represent $\mathrm{P}>0.05, *$ represent $\mathrm{P}<0.05$, ** represent $\mathrm{P}<0.01$, *** represent $\mathrm{P}<0.001$.

associated with $\mathrm{P}$ concentration. A previous study found that $\mathrm{P}$ deficiency induced the formation of brown iron plaques in the Oryza sativa root surface and accelerated plant $\mathrm{P}$ absorption [46], therefore, it was assumed that adequate $\mathrm{P}$ with $\mathrm{AMF}$ presence might have antagonistic effects on Fe absorption in return.

\section{Conclusions}

The main contributions of RI inoculation for switchgrass, in our study, were enhanced biomass and $\mathrm{P}$ nutrition, decreased $\mathrm{Cd}$ absorption and translocation from root to shoot, passivated soil Cd bioavailablility, decreased $\mathrm{Cd}$ and nutrient elements levels under a low $\mathrm{Cd}$ addition, and enhanced $\mathrm{Cd}$ antagonism effects with mineral elements under high $\mathrm{Cd}$ addition. Therefore, inoculation with AMF could relieve $\mathrm{Cd}$ toxicity in the switchgrass seedling stage. Since our study was conducted in the short-term in greenhouse conditions, more studies are needed to compare the different growth periods of switchgrass inoculated with AMF under artificial or field conditions and $\mathrm{Cd}$ stress. More physiological and molecular mechanisms are needed to illuminate AMF function under $\mathrm{Cd}$ stress.

\section{Acknowledgements}

The authors gratefully acknowledge grants received for this work from 863 Program (2012AA101802).

\section{Conflict of Interest}

The authors declare no conflict of interest.

\section{Reference}

1. CHEN B., LAI H., LEE D., JUANG K. Using Chemical Fractionation to Evaluate the Phytoextraction of cadmium by Switchgrass from Cd-Contaminated Soils. Ecotoxicology 20 (2), 409, 2011.

2. ZHANG X., ZHANG X., GAO B., LI Z., XIA H., LI H., LI J. Effect of cadmium on growth, photosynthesis, mineral nutrition and metal accumulation of energy crop, king grass (Pennisetum americanum $\times$ P. purpureum). Biomass Bioenergy 67, 179, 2014.

3. PERALTA-VIDEA J.R., LOPEZ M. L., NARAYAN M., SAUPE G., GARDEA-TORRESDEY J. The biochemistry of environmental heavy metal uptake by plants: implications for the food chain. Int. J. Biochem. Cell Biol. 41 (8-9), 1665, 2009.

4. ALI H., KHAN E., SAJAD M. A. Phytoremediation of heavy metals-concepts and applications. Chemosphere 91 (7), 869, 2013.

5. KOÇAR I., SCURLOCK J.M., LINDVALL E., CHRISTOU M. The development and current status of perennial rhizomatous grasses as energy crops in the US and Europe. Biomass Bioenergy 25 (4), 335, 2003.

6. KOÇAR G., CIVAŞ N. An overview of biofuels from energy crops: Current status and future prospects. Renew. Sust. Energ. Rev. 28 (8), 900, 2013.

7. PANDEY V.C., BAJPAI O., SINGH N. Energy crops in sustainable phytoremediation. Renew Sust Energ Rev, 54, 58, 2016.

8. WANG Q., GU M., MA X., ZHANG H., WANG Y., CUI J., CUI J. Model optimization of cadmium and accumulation in switchgrass (Panicum virgatum, L.): potential use for ecological phytoremediation in Cd-contaminated soils. Environ. Sci. Pollut. Res. 22 (21), 16758, 2015.

9. WANG Q., WU C., XIE B., LIU Y., CUI J., CHEN G., ZHANG Y. Model analysing the antioxidant responses of leaves and roots of switchgrass to $\mathrm{NaCl}$-salinity stress. Plant Physiol. Biochem. 58 (3), 288, 2012.

10. SÁNCHEZ E., GIL S, AZCÓN-BIETO J., NOGUÉS S. The response of Arundo donax L. $\left(\mathrm{C}_{3}\right)$ and Panicum virgatum $\left(\mathrm{C}_{4}\right)$ to different stresses. Biomass Bioenergy 85, 335, 2016.

11. ENTRY J. A., WATRUD L. S. Potential Remediation of ${ }^{137} \mathrm{Cs}$ and ${ }^{90} \mathrm{Sr}$ Contaminated Soil by Accumulation in Alamo Switchgrass. Water Air Soil Pollut. 104 (3-4), 339, 1998.

12. REED R.L., SANDERSON M.A., ALLEN V.G., MATCHES A.G. Growth and cadmium accumulation in selected switchgrass cultivars. Commun. Soil Sci. Plant Anal. 30 (19-20), 2655, 1999.

13. HUANG K.W., LAI H.Y., CHEN B.C. Coupling bioaccumulation and phytotoxicity to predict copper 
removal by switchgrass grown hydroponically. Ecotoxicology 20 (4), 827, 2011.

14. ARORA K., SHARMA S., MONTI A. Bio-remediation of $\mathrm{Pb}$ and $\mathrm{Cd}$ polluted soils by switchgrass: a case study in India. Int. J. Phytoremediat. 18 (7), 704, 2015.

15. CHEN B. D., ZHU Y. G., DUAN J., XIAO X., SMITH S. E. Effects of the arbuscular mycorrhizal fungus Glomus mosseae on growth and metal uptake by four plant species in copper mine tailings. Environ. Pollut. 147 (2), 374, 2007.

16. WU S., ZHANG X., SUN Y., REN B., WU Z., LI T., HU Y., SU D., LV J., LI G., ZHANG Z., ZHENG L., ZHANG J., CHEN B. Transformation and Immobilization of Chromium by Arbuscular Mycorrhizal Fungi as Revealed by SEM-EDS, TEM-EDS, and XAFS. Environ Sci. Tech. 49, 14036, 2015.

17. ZHANG X., CHEN B., OHTOMO R. Mycorrhizal effects on growth, $\mathrm{P}$ uptake and $\mathrm{Cd}$ tolerance of the host plant vary among different AM fungal species. Soil Sci. Plant Nutr, 61 (2), 359, 2015.

18. AUDET P., CHAREST C. Dynamics of arbuscular mycorrhizal symbiosis in heavy metal phytoremediation: Meta-analytical and conceptual perspectives. Environ. Pollut. 147 (3), 609, 2007.

19. LIU H., YUAN M., TAN S., YANG X., LAN Z., JIANG Q., YE Z., JING Y. Enhancement of arbuscular mycorrhizal fungus (Glomus versiforme) on the growth and Cd uptake by Cd-hyperaccumulator Solanum nigrum. Appl. Soil Ecol. 89, 44, 2015.

20. SHABANI L., SABZALIAN M. R., POUR S. M. Arbuscular mycorrhiza affects nickel translocation and expression of $\mathrm{ABC}$ transporter and metallothionein genes in Festuca arundinacea. Mycorrhiza, 26 (1), 67, 2015.

21. JONER E.J., LEYVAL C. Uptake of ${ }^{109} \mathrm{Cd}$ by roots and hyphae of a Glomus mosseae/Trifolium subterraneum, mycorrhiza from soil amended with high and low concentrations of cadmium. New Phytol. 135 (2), 353, 2008.

22. NAYUKI K., CHEN B. D., OHTOMO R., KUGA Y. Cellular imaging of cadmium in resin sections of arbuscular mycorrhizas using synchrotron micro X-ray fluorescence. Microbes Environ. 29 (1), 60, 2014.

23. YAO Q., YANG R., LONG L., ZHU H. Phosphate application enhances the resistance of arbuscular mycorrhizae in clover plants to cadmium via, polyphosphate accumulation in fungal hyphae. Environ. Exp. Bot. 108 (1), 63, 2014.

24. GONZÁLEZ-CHÁVEZ M.C., CARRILLO-GONZÁLEZ R., WRIGHT S.F., NICHOLS K.A. The role of glomalin, a protein produced by arbuscular mycorrhizal fungi, in sequestering potentially toxic elements. Environ. Pollut. 130 (3), 317, 2004.

25. RAJKUMAR M., SANDHYA S., PRASAD M.N.V., FREITAS H. Perspectives of plant-associated microbes in heavy metal phytoremediation. Biotech. Advan. 30 (6), 1562, 2012.

26. CLARK R. B., ZETO S. K., ZOBEL R.W. Arbuscular mycorrhizal fungal isolate effectiveness on growth and root colonization of Panicum virgatum in acidic soil. Soil Biol. Biochem. 31 (13), 1757, 1999.

27. SCHROEDER-MORENO M. S., GREAVER T. L., WANG S., HU S., RUFTY T.W. Mycorrhizal-mediated nitrogen acquisition in switchgrass under elevated temperatures and $\mathrm{N}$ enrichment. GCB Bioenergy, 4 (3), 266, 2011.

28. GIOVANNETTI M, MOSSE B. Evaluation of techniques for measuring vesicular arbuscular mycorrhizal infection in roots. New Phytol. 84 (3), 489, 1980.
29. PHILLIPS J.M., HAYMAN D.S. Improved procedures for clearing roots and staining parasitic and vesicular-arbuscular mycorrhizal fungi for rapid assessment of infection. Transactions of the British Mycological Society, 55 (1), 158, 1970.

30. DE ANDRADE S.A., DA S.A., JORGE R.A., DE ABREU M.F. Cadmium accumulation in sunflower plants influenced by arbuscular mycorrhiza. Int. J. Phytoremediat. 10 (1), 1, 2008.

31. LI H., LUO N., ZHANG L., ZHAO H., LI Y., CAI Q., WONG M., MO C. Do arbuscular mycorrhizal fungi affect cadmium uptake kinetics, subcellular distribution and chemical forms in rice? Sci. Total Environ. 571, 1183, 2016

32. AGHABABAEI F., RAIESI F., HOSSEINPUR A. The combined effects of earthworms and arbuscular mycorrhizal fungi on microbial biomass and enzyme activities in a calcareous soil spiked with cadmium. Appl. Soil Ecol. 75 (1), 33, 2014.

33. JIANG Q.Y., TAN S.Y., ZHUO F., YANG D., YE Z., JING Y. Effect of Funneliformis mosseae on the growth, cadmium accumulation and antioxidant activities of Solanum nigrum. Appl. Soil Ecol. 98, 112, 2016.

34. WEISSENHORN I., LEYVAL C., BERTHELIN J. Cd-tolerant arbuscular mycorrhizal (AM) fungi from heavy-metal polluted soils. Plant Soil 157, 247, 1993.

35. TURNAU K., KOTTKE I., OBERWINKLER F. Element localization in mycorrhizal roots of Pteridium aquilinum (L.) Kuhn collected from experimental plots treated with cadmium dust. New Phytol. 123 (2), 313, 1993.

36. AMIR H., LAGRANGE A., HASSAÏNE N., CAVALOC Y. Arbuscular mycorrhizal fungi from New Caledonian ultramafic soils improve tolerance to nickel of endemic plant species. Mycorrhiza 23 (7), 585, 2013.

37. SHEN H., LIU Y., LI X., CHENG B., FENG G., BAI S. Influence of arbuscular mycorrhizal fungus (Glomus caledonium) on maize seedlings grown in copper contaminated soil. Plant Nutr. Fertiliz Sci. 11 (2), 199, 2005.

38. CORNEJO P., MEIER S., BORIE G., RILLING M.C., BORIE F. Glomalin-related soil protein in a Mediterranean ecosystem affected by a copper smelter and its contribution to $\mathrm{Cu}$ and $\mathrm{Zn}$ sequestration. Sci. Total Environ. 406 (1), 154, 2008.

39. SUBRAMANIAN K.S., TENSHIA V., JAYALAKSHMI K., RAMACHANDRAN V. Biochemical changes and zinc fractions in arbuscular mycorrhizal fungus (Glomus intraradices) inoculated and uninoculated soils under differential zinc fertilization. Appl. Soil Ecol. 43 (1), 32, 2009.

40. WU S., CHEN B., SUN Y. REN B., ZHANG X., WANG Y. Chromium resistance of dandelion (Taraxacum platypecidum, Diels.) and bermudagrass (Cynodon dactylon, [Linn.] Pers.) is enhanced by arbuscular mycorrhiza in $\mathrm{Cr}(\mathrm{VI})$-contaminated soils. Environ. Toxicol. Chem. 33 (9), 2105, 2014.

41. KUMAR P., LUCINI L., ROUPHAEL Y., CARDARELLI M., KALUNKE R.M., COLLA G. Insight into the role of grafting and arbuscular mycorrhiza on cadmium stress tolerance in tomato. Front. Plant Sci. 6, 477, 2015.

42. SARKAR A., ASAEDA T., WANG Q., RASHID M., H. Arbuscular mycorrhizal influences on growth, nutrient uptake, and use efficiency of Miscanthus sacchariflorus growing on nutrient-deficient river bank soil. Flora. 212, 46-54, 2015.

43. WANG L., HUANG X., MA F., HO S. H., WU J., ZHU S. Role of Rhizophagus irregularis in alleviating cadmium toxicity via improving the growth, micro- and macroelements uptake in Phragmites australis. Environ. Sci. Pollut. Res. 24, 3593, 2017.

44. DE LA ROSA G., MARTÍNEZ-MARTÍNEZ A., PELAYO H., PERALTA-VIDEA J.R., SANCHEZ-SALCIDO B., GARDEATORRESDEY J.L. Production of low-molecular weight thiols as a response to cadmium uptake by tumbleweed (Salsola kali). Plant Physiol Biochem 43, 491, 2005.

45. WEBSTER S.M., DEL CAMINO D., DEKKER J.P., YELLEN G. Intracellular gate opening in Shaker $\mathrm{K}^{+}$channels defined by highaffinity metal bridges. Nature 428, 864, 2004.

46. FU Y.Q., YANG X.J., WU D.M., SHEN H. Effect of phosphorus on reddish brown iron plaque on root surface of rice seedlings and their nutritional effects. Scientia Agricutura Sinica. 47, 1072, 2014. 
